\title{
An Infrared Thermography Approach to Evaluate the Strength of a Rock Cliff
}

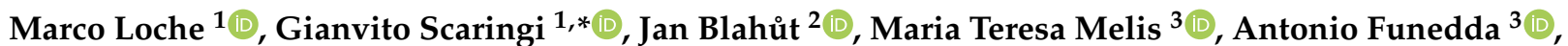 \\ Stefania Da Pelo ${ }^{3}{ }^{(0)}$, Ivan Erbì ${ }^{3}$, Giacomo Deiana ${ }^{3}{ }^{-}$, , Mattia Alessio Meloni ${ }^{3}$ and Fabrizio Cocco ${ }^{3}$
}

Citation: Loche, M.; Scaringi, G.; Blahůt, J.; Melis, M.T.; Funedda, A.; Da Pelo, S.; Erbì, I.; Deiana, G.; Meloni, M.A.; Cocco, F. An Infrared Thermography Approach to Evaluate the Strength of a Rock Cliff. Remote Sens. 2021, 13, 1265. https://doi.org/ $10.3390 /$ rs13071265

Academic Editors: Javier

\section{Cardenal Escarcena, Jorge}

Delgado García and Joaquim João Sousa

Received: 27 February 2021

Accepted: 25 March 2021

Published: 26 March 2021

Publisher's Note: MDPI stays neutral with regard to jurisdictional claims in published maps and institutional affiliations.

Copyright: (c) 2021 by the authors. Licensee MDPI, Basel, Switzerland. This article is an open access article distributed under the terms and conditions of the Creative Commons Attribution (CC BY) license (https:/ / creativecommons.org/licenses/by/ $4.0 /)$.
1 Institute of Hydrogeology, Engineering Geology and Applied Geophysics, Charles University, Albertov 6, 12843 Prague, Czech Republic; marco.loche@natur.cuni.cz

2 Institute of Rock Structure \& Mechanics, Czech Academy of Sciences, V Holešovičkách 41, 18209 Prague, Czech Republic; blahut@irsm.cas.cz

3 Department of Chemical and Geological Sciences, University of Cagliari, Cittadella Universitaria-S.S. 554 Bivio per Sestu I, 09042 Monserrato, Cagliari, Italy; titimelis@unica.it (M.T.M.); afunedda@unica.it (A.F.); sdapelo@unica.it (S.D.P.); ivanerbi@hotmail.it (I.E.); giacomo.deiana@unica.it (G.D.); melonimattiaalessio@tiscali.it (M.A.M.); fabrcocco@unica.it (F.C.)

* Correspondence: gianvito.scaringi@natur.cuni.cz

\begin{abstract}
The mechanical strength is a fundamental characteristic of rock masses that can be empirically related to a number of properties and to the likelihood of instability phenomena. Direct field acquisition of mechanical information on tall cliffs, however, is challenging, particularly in coastal and alpine environments. Here, we propose a method to evaluate the compressive strength of rock blocks by monitoring their thermal behaviour over a $24-\mathrm{h}$ period by infrared thermography. Using a dronemounted thermal camera and a Schmidt (rebound) hammer, we surveyed granitoid and aphanitic blocks in a coastal cliff in south-east Sardinia, Italy. We observed a strong correlation between a simple cooling index, evaluated in the hours succeeding the temperature peak, and strength values estimated from rebound hammer test results. We also noticed different heating-cooling patterns in relation to the nature and structure of the rock blocks and to the size of the fractures. Although further validation is warranted in different morpho-lithological settings, we believe the proposed method may prove a valid tool for the characterisation of non-directly accessible rock faces, and may serve as a basis for the formulation, calibration, and validation of thermo-hydro-mechanical constitutive models.
\end{abstract}

Keywords: compressive strength; infrared thermography; rebound hammer; cooling rate index

\section{Introduction}

The mechanical characterisation of rock masses has been the object of extensive research for decades [1,2]. Despite significant advances brought by improved instruments and methodologies, standard classifications-relying on the evaluation of rock strength and fracture networks [3]-remain widely utilised in direct field surveys [4-7]. The rock strength, defined as the resistance to permanent deformation by flow or fracture, is often estimated by the Schmidt (rebound) hammer test [8-14]. Direct surveying and groundbased monitoring, however, can be unfeasible if the rock outcrops are located in inaccessible areas, such as steep mountain ridges or coastal cliffs [15-18]. Efforts are therefore being made on formulating alternative methods relying on remote sensing techniques for the definition of input data for empirical and physically-based models [19-24].

Coastal cliffs are dynamic environments featuring frequent and rapid mass movements that can pose significant hazards to people, infrastructures, and ecosystems [25]. The stability of coastal cliffs is particularly sensitive to changes in hydro-meteorological forcing [26]. More frequent extreme weather conditions resulting from global warming may enhance physical weathering, instability phenomena, and cliff retreat in some regions [27]. Higher temperatures may also accelerate chemical weathering [27-29]. 
The use of unmanned aerial vehicles (UAVs) to perform detailed observations of non-directly accessible areas has become increasingly common, both to characterise rock mass geometries and to detect surface changes and movements [30-34]. Sensors operating in various ranges of the spectrum (Table S1) can be installed on board of UAVs, typically exploring the visible and infrared wavelengths in a similar fashion as the sensors installed on satellites, but without the limitations of fixed passing times and atmospheric shadowing. Depending on the desired precision and the extent of the study area, observations can also be performed from static locations on the ground.

Infrared thermography (IRT) is a remote sensing technique by which the surface temperature of a body can be evaluated from its thermal radiation [35-39]. Rocks behave as grey bodies, and the energy they emit follows Stefan-Boltzmann's law: $\mathrm{J}=\varepsilon \theta \mathrm{T}^{4}$, where $\mathrm{J}$ is the total energy emitted by a body, $\mathrm{T}$ is its surface temperature, $\varepsilon$ is the emissivity, and $\theta$ is Stefan-Boltzmann's constant [40]. Assessing the energy balance during a heating phase can be complex owing to the direct (and at times inconstant) exposure of the rock to solar radiation. Conversely, the evaluation T during a subsequent cooling phase, that is when the body re-equilibrates with the ambient temperature, is simpler and more viable [41].

The potential of IRT in geosciences has been first demonstrated in the seminal work of Hudson [42]. Since then, several applications have been proposed thanks to the technological development of thermal sensors and acquisition systems [16]. Volcano monitoring [43-46], underground mining [36], cave exploration [47], and geothermal analyses [48] can benefit from IRT technologies. Landslide and rockfall mapping by IRT also have been attempted [37,39,49-54] (Table 1).

Thermal anomalies in rock masses can be related to the presence of loosened material and open fractures [55]. IRT monitoring during cooling can inform on the degree of fracturing in the field [41] and porosity in the laboratory [56,57]. These characteristics also affect the mechanical strength [3]. Therefore, the use of IRT to evaluate rock mechanical properties can be hypothesised. Indeed, here we present preliminary results of an IRT application to the prediction of the compressive strength of rock blocks in a portion of a 30-m high landslide-prone coastal cliff (Cala Delfino, south-east Sardinia, Italy; Figure 1). We demonstrate that the cooling trend of the rock blocks can be related with conventionally-evaluated rock strength values, and we define a cooling rate index (CRI) to obtain quantitative predictions through regression analysis.

Table 1. Features investigated by IRT in recent studies.

\begin{tabular}{|c|c|c|}
\hline Ref. & Platform (Distance Object-Sensor) & Features \\
\hline [58] & Terrestrial & Eroded caves in a shotcreted slope \\
\hline [37] & Terrestrial (120-150 m) & $\begin{array}{l}\text { Shallow inhomogeneities, weathered rock cliff } \\
\text { areas }\end{array}$ \\
\hline [23] & Terrestrial & $\begin{array}{l}\text { Main joints, recently collapsed areas/detachments } \\
\text { in a coastal cliff }\end{array}$ \\
\hline [47] & Terrestrial, UAV & $\begin{array}{l}\text { Open cracks, tension and loosened zones, } \\
\text { pseudo-karst caverns }\end{array}$ \\
\hline $\begin{array}{l}{[41,} \\
55]\end{array}$ & Terrestrial (3 m) & $\begin{array}{l}\text { Geostructural features, fracturing degree, daytime } \\
\text { temperature exchange of a rock slope }\end{array}$ \\
\hline [39] & Terrestrial & $\begin{array}{l}\text { Thermal contrast between vegetated, weathered } \\
\text { and bare rock areas of an unstable slope }\end{array}$ \\
\hline [59] & Terrestrial & Discontinuity system of a rock wedge \\
\hline [51] & Terrestrial, airborne & $\begin{array}{l}\text { Wedge fractures, erosional channels, scarps, } \\
\text { earthflow ponds, seepage sectors, debris cones }\end{array}$ \\
\hline$[60]$ & Terrestrial & $\begin{array}{l}\text { Surficial temperature, thermal response of jointed } \\
\text { blocks, seasonality }\end{array}$ \\
\hline [61] & Terrestrial (20 m) & $\begin{array}{l}\text { Spatio-temporal surficial temperature pattern of a } \\
\text { rock mass arch }\end{array}$ \\
\hline [53] & Terrestrial $(600 \mathrm{~m})$ & $\begin{array}{l}\text { Weathering rock areas, moisture content related to } \\
\text { the ephemeral drainage network }\end{array}$ \\
\hline
\end{tabular}




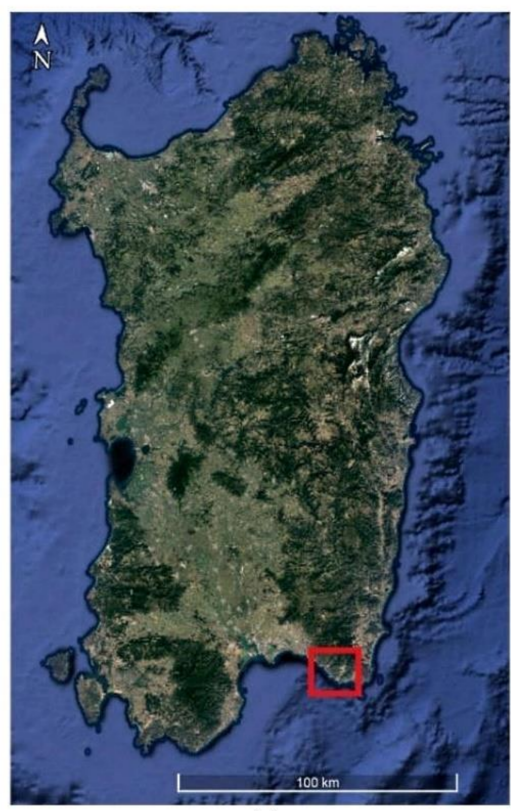

(a)

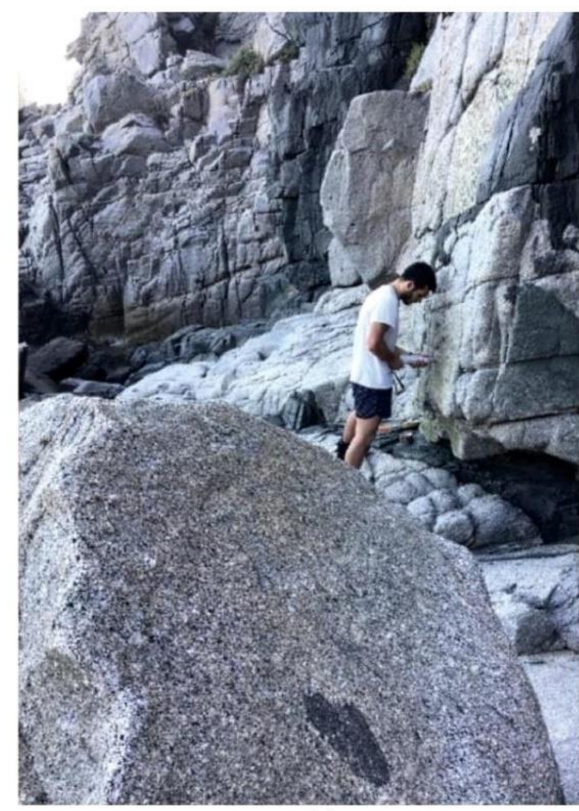

(b)

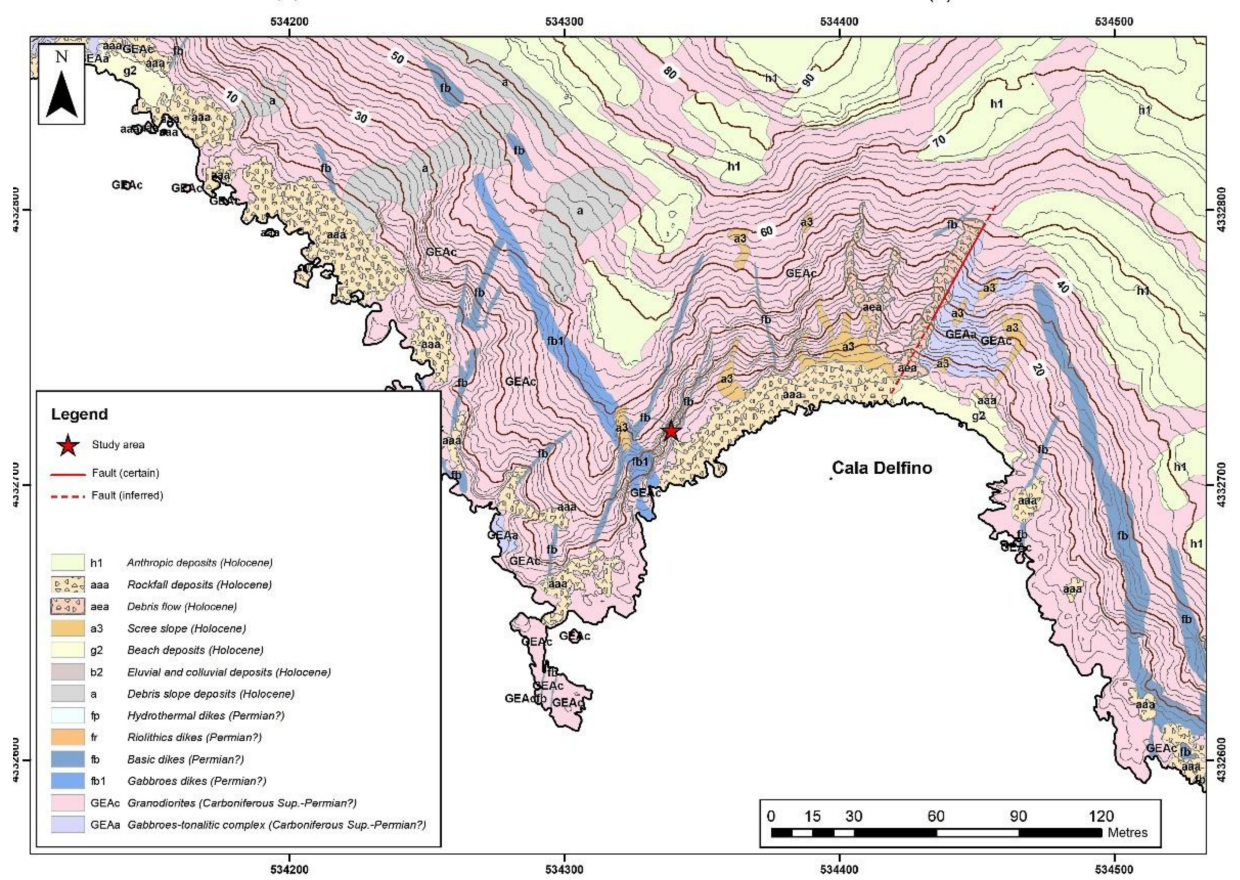

(c)

Figure 1. (a) Location of the study area; (b) rebound hammer test; (c) geological map. The plutonic rocks belong to the Geremeas intrusive Unit (GEA) [62]. Coarse-grained, equigranular to moderately inequigranular Granodiorites (GEAc) are present, with medium-fine grained, greenish-grey enclaves of gabbro-tonalitic masses (GEAa). The dikes crosscutting the unit are generally vertical, 1-10 m thick, NNW- and, subordinately, NE-trending. They are basaltic to andesitic dikes (fb), grey-green to blackish, with aphanitic to microcrystalline or porphyritic structure for phenocrysts of feldspar and/or amphibole, and gabbroid dikes (fb1), dark grey, with microgranular structure for plagioclase, pyroxene and quartz. The stabilised slope deposits (a) consist of debris accumulations of angular clasts, locally with matrix, at times partially compacted and stabilised. Eluvial-colluvial deposits (b2) are made of debris in a fine matrix, sometimes intercalated with more or less evolved soils, organic-enriched. Beach deposits (g2) are made of current sands, gravels and pebbles with local remains of Posidonia oceanica. The active slope deposits (a3) are still evolving, chaotic accumulations of incoherent clasts in a finer matrix, mainly of weathered granitoids. Rockfall deposits (aaa) consist of dm- to m-sized angular blocks. Debris flow deposits (aea) are unsorted, chaotic angular clasts, blocks, plant remains, with some anthropic material in a fine sandy-silty matrix. Anthropic deposits (h1) from manufactures and filling materials are also present. 


\section{Site Characterisation}

The study site is located in the Variscan crystalline basement of south-east Sardinia, Italy (Figure 1), and is part of the Sàrrabus igneous massif $\left(400 \mathrm{~km}^{2}\right)$, a composite intrusive complex related to the late phase of the Variscan orogeny, emplaced between $305 \mathrm{Ma}$ and $285 \mathrm{Ma}$ in the frontal part of the orogenic wedge [63]. Here, the crystalline basement is characterised by two lithofacies of plutonic rocks intruded by a Permian dike complex, both covered by thin Quaternary, continental to littoral sediments. These consist of eluviumcolluvial layers, slope deposits, debris flow and rockfall deposits, contemporary beach deposits, and small anthropic deposits. Rockfall deposits are widespread at the base of the cliffs and along the small bays. They consist of angular blocks of variable size $\left(\mathrm{dm}^{3}\right.$ to $\left.\mathrm{m}^{3}\right)$; the largest blocks are mainly from the granodioritic and tonalitic lithofacies.

The basements rocks exhibit a widespread fracture network, where two different systems - related to the late Variscan evolution — can be distinguished and often bear ore deposits in adjacent areas [64]. At the map scale, the NNW-trending fracturing dominates, and affects the whole Sàrrabus region for more than $50 \mathrm{~km}$ to the north [65]. The main Permian dikes follow this trend. A NE-trending system is also present, with minor dikes. At the outcrop scale, some other systems can be seen, with attitudes from vertical to subhorizontal. The latter are joints related to the after-emplacement cooling of the intrusive bodies and their post-orogenic exhumation. In adjacent areas, evidence exist that these fractures have been reactivated during the Tertiary and Plio-Pleistocene evolution [66].

The juxtaposition of outcropping lithologies with different compositions makes the use of IRT favourable for characterising their properties. Within this context, we performed a 24-h long thermal monitoring of a cliff that borders the tourist beach of Cala Delfino. Along the cliff, the size of the rock blocks ranges from less than one metre to several metres (Figure 1b). We selected three blocks with dimensions of $2 \mathrm{~m} \times 0.5 \mathrm{~m}$ (block A), $1 \mathrm{~m} \times 1 \mathrm{~m}$ (block B), and $0.5 \mathrm{~m} \times 0.5 \mathrm{~m}$ (block C) (Figure 2a). Macroscopically, the blocks present either uniform or no fracturing. Blocks A and B consist of granodiorites, while the darker block $\mathrm{C}$ consists of basic glass-free hypocrystalline aphanitic rocks. In thin sections, quartz and chloritised biotite in the groundmass were observed. Several amphiboles and large plagioclase crystals were also found. Micro-fractures systems were observed, marked by chlorite or iron oxides. According to the volumetric joint count (Jv; [67]), defined as the number of joints intersecting a volume of $1 \mathrm{~m}^{3}$, the blocks were attributed to three different classes (Table S2): very low Jv-massive block with no visible fractures (block A); low Jv-massive block with small fractures (block C); moderate Jv—continuous block with regular fracturing degree (block B).
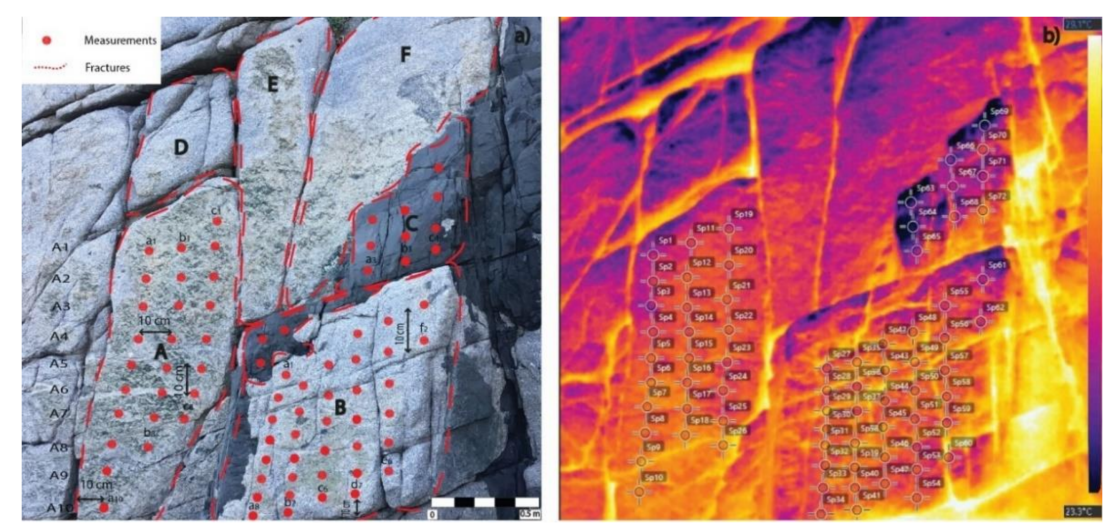

Figure 2. Acquisition scheme (a) in the field, where 10 rebound tests were performed at each point, and (b) in FLIR Tools software, where each point corresponds to a spot measurement within the thermogram. The image in (b) was acquired at 22:00. 


\section{Materials and Methods}

The rock strength $\left(\sigma_{\mathrm{c}}\right)$ was evaluated through rebound hammer tests, as a strong correlation $[8,14]$ can be properly estimated in the laboratory following conventional procedures $[9,10,68]$. Figure $2 \mathrm{a}$ displays the points where the tests were performed following ASTM recommendations. Ten readings were taken at each point (red dots: e.g., a1, b1, c1). Considering that $\sigma_{\mathrm{c}}$ is strongly influenced by the density, distribution and connectivity of the microstructures, in order to reflect the potential spread of the values resulting from rock heterogeneity, block-level mean, median, mode and standard deviation values were also computed. The temperature of each point in each thermogram was also evaluated, so that the surface temperature of each block through time could be assessed and its trend related with the rock strength.

Thermal data were acquired during the summer season (from 12:00 p.m. on 23 June 2020 to 12:00 p.m. on 24 June 2020) through a drone-mounted FLIR XT2 camera (Table S3). The drone, in our specific application, was installed on a fixed platform to ensure stability even under a breeze, and continuous monitoring for the desired period of time (Figure 3a). The shooting point was located about $5.4 \mathrm{~m}$ from the rock face to record images with sufficient detail at an approximately perpendicular angle. After processing, each pixel of the recorded image (e.g., Figure $2 b$ ) represented a value of surface temperature.

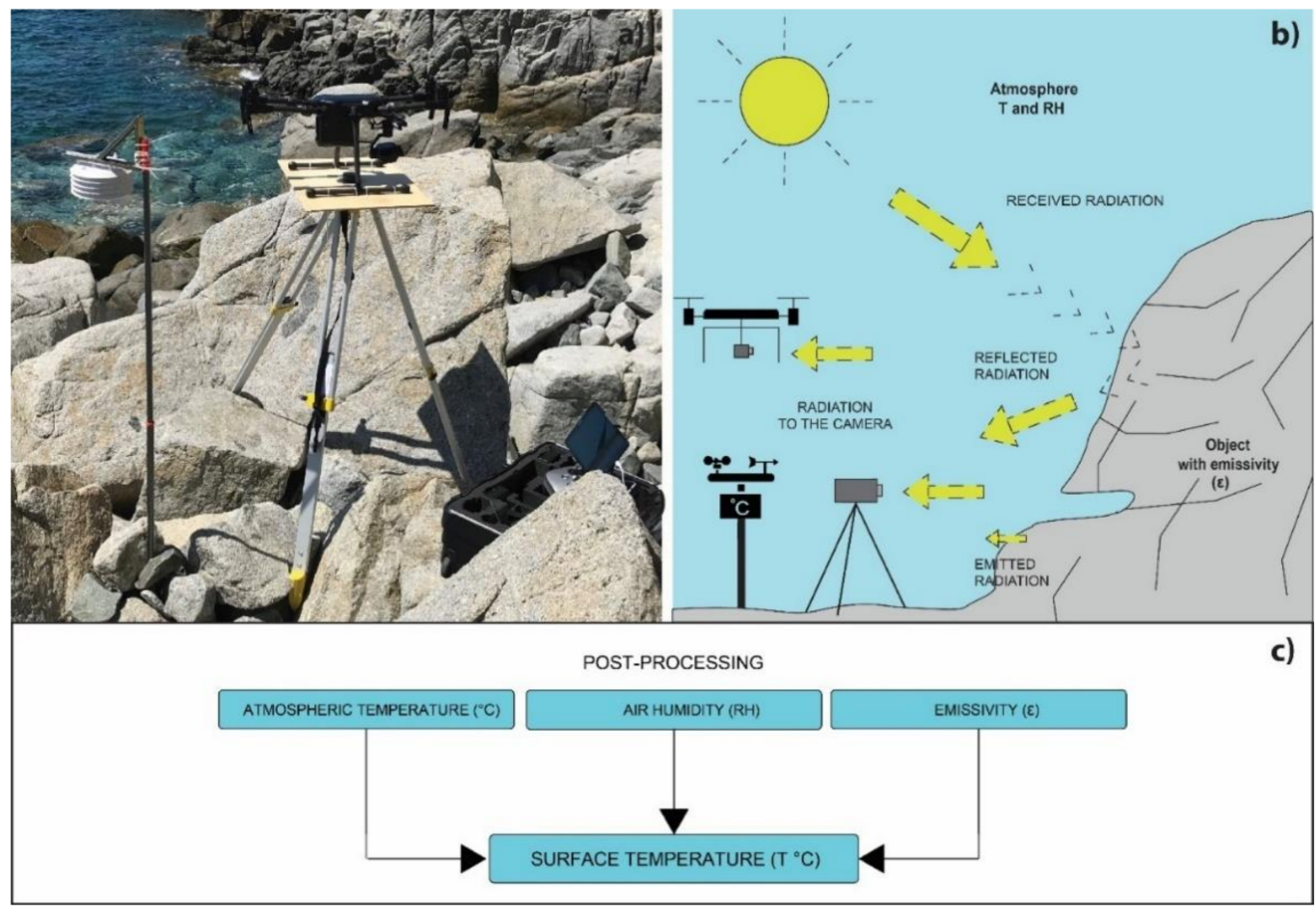

Figure 3. (a) Drone and weather station; (b) schematic of the acquisition system (a ground-based solution was adopted in this work) and heat transfers between the cliff and the atmosphere [16]; (c) post-processing scheme.

The blocks were directly exposed to solar radiation during the morning $(7-12 \mathrm{~h})$ given their south-east exposure. In the afternoon and night (13-7 h), they gradually released the heat into the environment (Figure $3 \mathrm{~b}$ ). Thermograms were acquired at 60-min intervals for $24 \mathrm{~h}$. Air humidity and temperature were recorded through a weather station (Table S4) to calibrate the thermograms during image post-processing. (Figure 3c). Emissivity was assumed according to Öhman [69].

The digital elaboration of the IRT images was carried out using FLIR Tools (FLIR Systems, Inc. Wilsonville, OR, USA), a software package designed to edit radiometric images that allows the evaluation of temperatures at specific points, along lines, or over 
areas. Point and line measurements were used to define individual blocks and fractures, respectively. The temperature of a block surface was estimated by averaging the point measurements, which were taken over a regular grid corresponding to that used for the rebound tests (Figure 2). In this way, the difference of temperature within the same thermogram could be highlighted, and specific temperature ranges could be isolated to define the best representative output. The average temperature of the block face was calculated by a point function, allowing a weighted measure of the face for each thermogram for $24 \mathrm{~h}$. The resulting values were elaborated to determine the cooling and heating phases (Figure 4).

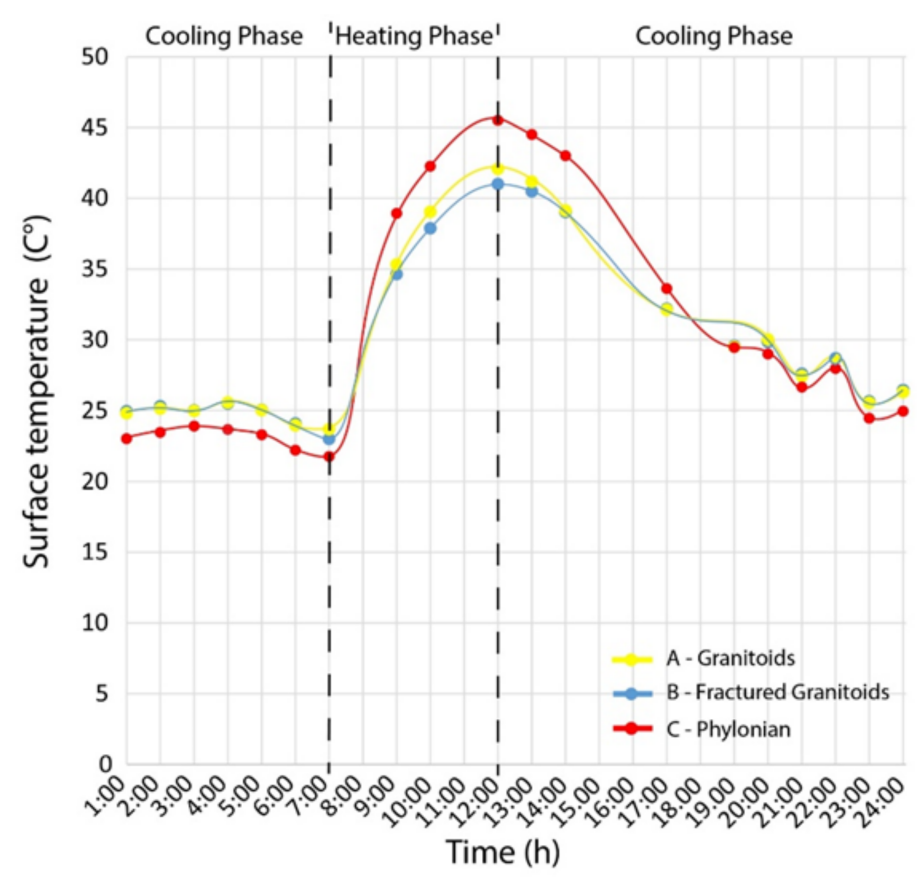

Figure 4. Cooling and heating phases computed from thermograms over $24 \mathrm{~h}$.

Different rocks may express different cooling properties, which we characterised in terms of a cooling rate index $([41,57])$ that quantifies the variation of temperature $\left(\Delta \mathrm{T},{ }^{\circ} \mathrm{C}\right)$ per unit time $(\Delta \mathrm{t}, \mathrm{h})$ as: $\mathrm{CRI}=\Delta \mathrm{T} / \Delta \mathrm{t}$.

\section{Results and Discussion}

We calculated the mean, median, mode, standard deviation (SD) and range of the rebound values for each block (Table 2 ).

Table 2. Rebound number statistics of the assessed blocks.

\begin{tabular}{ccccccc}
\hline Block & ASTM & Mean & Median & Mode & SD & Range \\
\hline A & 53 & 53 & 54 & 58 & 9 & $18-69$ \\
B & 49 & 49 & 50 & 52 & 11 & $18-68$ \\
C & 60 & 59 & 60 & 62 & 5 & $35-68$ \\
\hline
\end{tabular}

With the ASTM method, three extreme values are discarded for each point, and the remaining values are averaged to give the point rebound number, then averaged again to give the block rebound number. The mean is computed over all readings on each block (10 readings per point, 10 points per block). Median, mode, standard deviation and range also are computed over all readings. A slight asymmetry in the dataset can be recognised from the median and modal values being larger than the mean. However, differences among the statistics are minor, and the estimated compressive strength values do not differ much either. Using the ASTM method and the empirical relationship provided in the hammer 
specifications ( $\sigma_{c}=0.0232 \times R^{2.2637}$, where $R$ is the rebound number), the following strength values are obtained: block A, $186 \mathrm{MPa}$; block B, $156 \mathrm{MPa}$; block C, $246 \mathrm{MPa}$. Using the mean of all measurements, the strength of block $C$ would be $237 \mathrm{MPa}$, while those of blocks $A$ and $B$ would remain unchanged. The use of median or modal values would lead to $12-23 \%$ higher strength estimates. Uncertainty $( \pm 1 \mathrm{SD})$ on the strength is $36 \%$ on average. This may seem a large value, yet we will demonstrate that it does not hinder a strong correlation with the CRI.

Physically, the different strength of blocks A and B, notwithstanding the similar lithology, can be attributed to the different degree of fracturing. Following Deere \& Miller's classification [70] (Table S5) block C can be classified as a very hard rock while blocks A and $\mathrm{B}$ as hard rocks.

The thermograms captured the heating-cooling cycle of the cliff during a 24-h period. By comparing images taken during the day and during the night (Figure 5), it is apparent that different zones are heated and cool differently. In particular, clean faces and corners (according to the diffusion equation) are the first surfaces to lose the heat adsorbed during the day. The thermal behaviour of fractures is likely influenced by air circulation within them, and therefore may be informative, to some extent, of the internal thermal state of the rock mass [41]. In fact, fractures appear relatively cooler during daytime and relatively warmer during the night. The morphology and structure of the blocks also can influence their heating-cooling behaviour. Block C, constituted by basic rock (more similar to a black body) with weak degree of fracturing, tends to lose the heat more homogeneously than the other blocks.
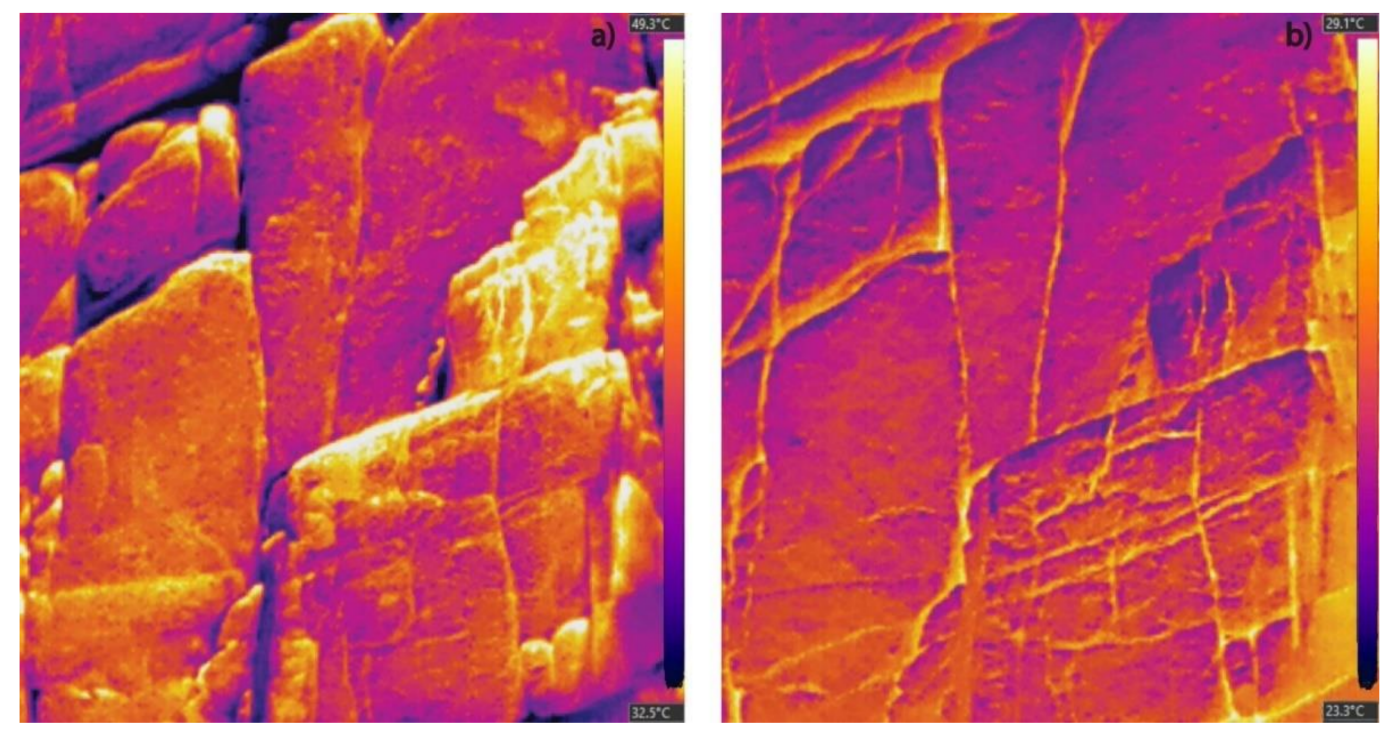

Figure 5. Thermograms recorded at (a) midday and (b) midnight where small fractures show less heat compared with larger ones.

To obtain a quantitative insight, we elaborated the images numerically, and estimated temperature values at the locations where the rebound hammer test was performed. The blocks located in unreachable locations and the discontinuities were also analysed. The average temperature of each block or discontinuity in each thermogram was evaluated and plotted against time (Figure 6). With reference to the day-night cycle, the temperature increased rapidly on the block faces during the morning hours under direct exposure to solar radiation and reached a peak at 12:00 p.m.; then, the rock gradually cooled throughout the afternoon and evening, and the temperature remained substantially stable from midnight to the following morning. The heating-cooling pattern was similar for all blocks. However, the amplitude of the thermal oscillation was different: it was larger for block C (aphanitic) than for blocks A and B (granitoids). 
The results support the hypothesis that the cooling behaviour of rock surfaces can be related to their inner macroscopic structure. The cooling phase is simpler to model than the heating phase as it occurs with smaller environmental disturbance. Conversely, in the morning hours, the heat balance depends on both the solar irradiance (direct and reflected by surrounding bodies) and the heat transfer from the rock to the atmosphere (generally cooler) supported by air convection. The rate of change in the temperature of a body is proportional to the difference with the ambient temperature. A faster cooling rate can therefore be indicative of a higher body temperature, provided that heat capacity and conductivity remain the same. Different structures (e.g., massive blocks or fractured rocks) can exhibit different cooling behaviours in relation to the different surface available for heat exchange, the role played by air convection, but also the insulating effect of the latter. In fact, air convection seems to prevail in our study case: the massive block $C$ cools faster than block B, which has strong fracturing and different lithology (Figure 6). The thermal behaviour of the fractures differs from that of the blocks: lower temperatures during the day and higher temperatures during the night are recorded compared with those of the blocks. This signals an insulating effect of the air, and a role played by convection in keeping the inner part of the rock relatively cooler during daytime and warmer during the night. Furthermore, we observe that small fractures retain less heat compared with the larger ones (Figure 5). This may allow for an IRT-based hierarchisation of fractures.
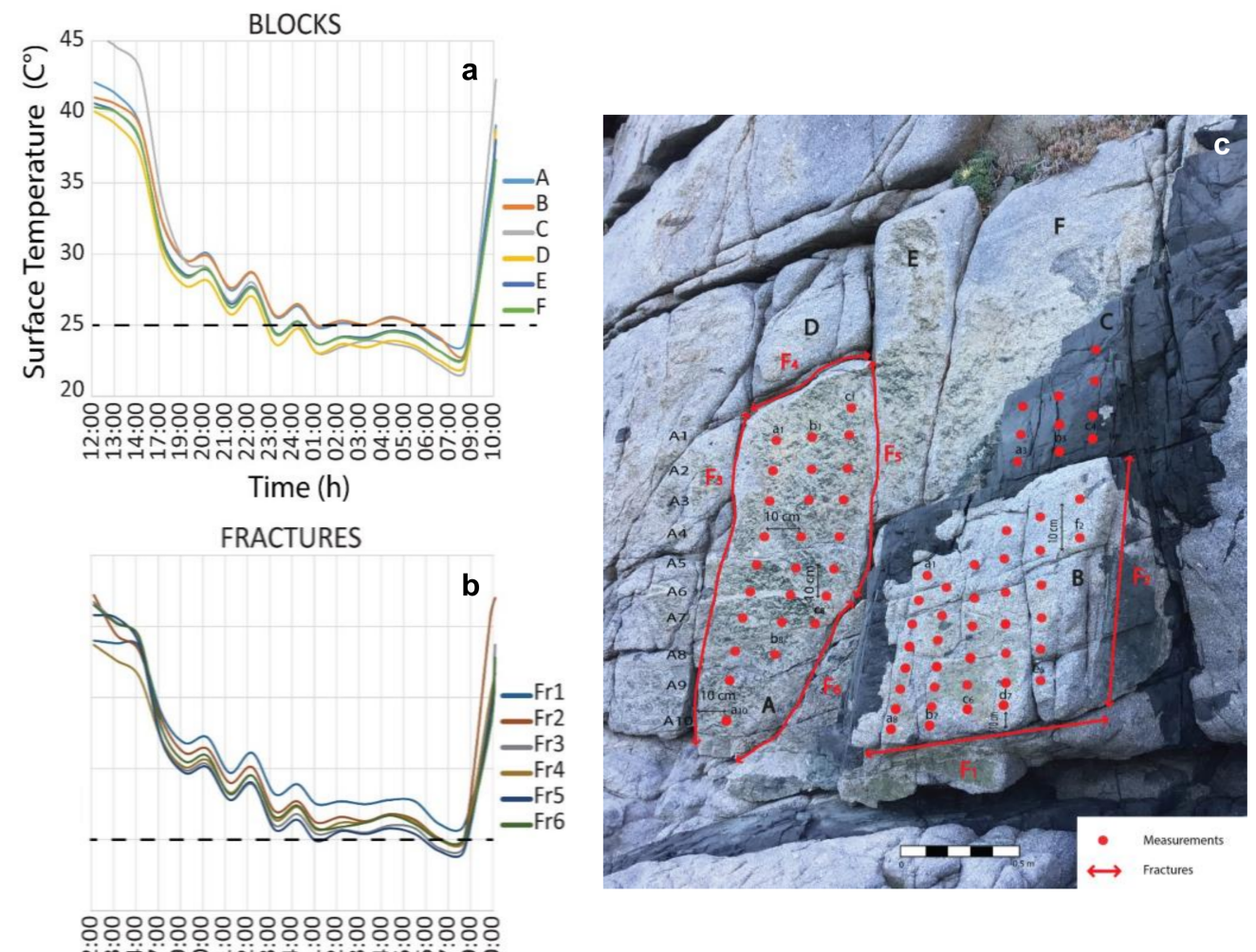

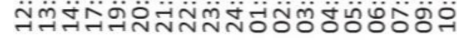
Time (h)

Figure 6. Cooling and heating patterns of (a) blocks and (b) fractures computed by thermograms. Blocks and fractures are shown in (c): Fr1 and Fr2 are open fractures with a length of $0.6 \mathrm{~m}$; Fr3 is a semi-open fracture with a length of $1.2 \mathrm{~m}$; Fr4 is an open fracture with a length of $0.4 \mathrm{~m}$; Fr5 is a semi-open fracture with a length of $0.7 \mathrm{~m}$; and Fr6 is a semi-open fracture with a length of $0.6 \mathrm{~m}$.

We performed a regression analysis between the estimated rock strength and the CRI of blocks A, B, and C. A positive correlation between CRI and Jv has been highlighted in the literature in smaller domains, without focusing on block-scale mechanical features or performing systematic temporal data acquisition [41]. Here, we explored different time intervals to define the CRI. Qualitatively, the different cooling behaviours of the blocks 
are particularly evident in the first hours of cooling (i.e., from 12:00 to 17:00), when the thermal gradients are the strongest. In fact (Figure 7) we found the highest coefficient of determination $\left(\mathrm{R}^{2}>0.99\right)$ between the rock strength and the CRI evaluated over the first five hours of cooling $\left(\mathrm{CRI}_{5 \mathrm{~h}}, 12: 00-17: 00\right)$. Smaller correlations are evaluated for shorter time intervals, i.e., with $\mathrm{CRI}_{1 \mathrm{~h}}\left(12: 00-13: 00, \mathrm{R}^{2}=0.75\right)$ and $\mathrm{CRI}_{2 \mathrm{~h}}\left(12: 00-14: 00, \mathrm{R}^{2}=0.13\right)$. A strong correlation is also seen with the Total CRI $\left(\mathrm{R}^{2}>0.97\right)$, which expresses the total thermal excursion from midday to the following morning (12:00-07:00). The identification of $\mathrm{CRI}_{5 \mathrm{~h}}$ as the most informative index has a practical implication as it suggests that a 24-h thermal monitoring would be superfluous and could be replaced by a shorter monitoring period to cover only the first hours of cooling, which are associated with the dissipation of the strongest thermal gradients. However, this finding needs to be confirmed on different lithologies, structures, and spatial scales.
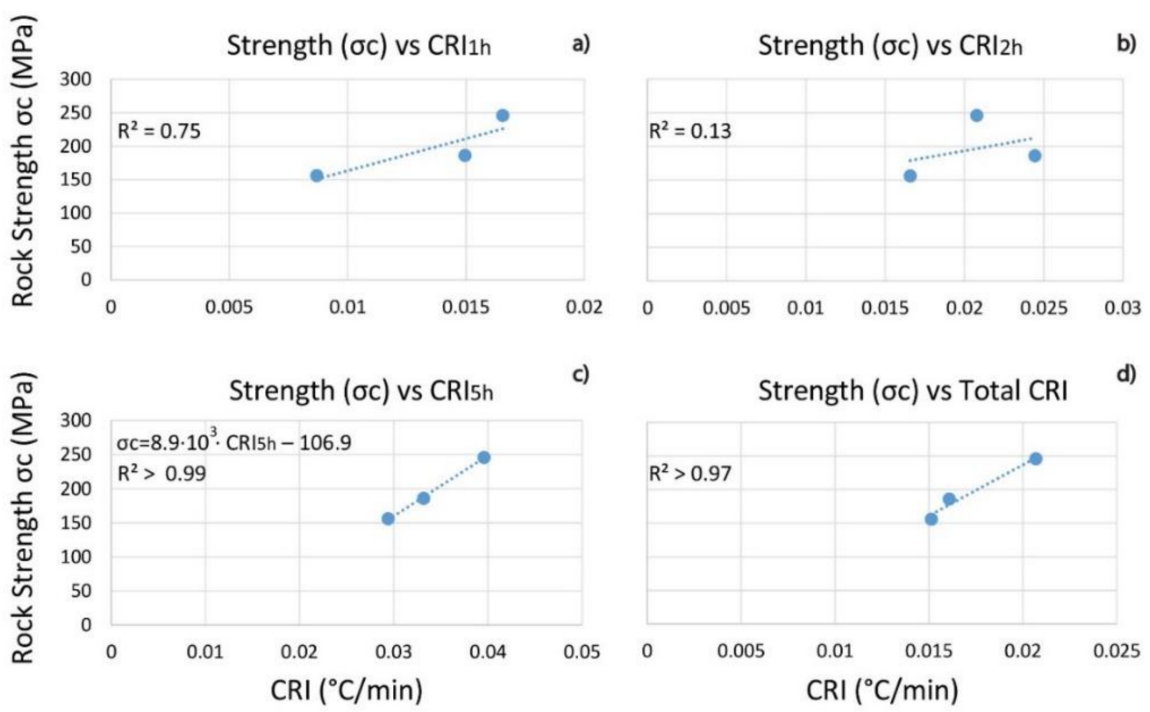

Figure 7. Linear regression analysis between rock strength $\left(\sigma_{\mathrm{c}}\right)$ and CRI according to different time intervals since the beginning of cooling: (a) $1 \mathrm{~h}$; (b) $2 \mathrm{~h}$; (c) $5 \mathrm{~h}$; (d) entire cooling phase. The markers represent the mean values for blocks $\mathrm{A}, \mathrm{B}$ and $\mathrm{C}$.

We evaluated the robustness of our correlations by performing a Monte-Carlo simulation (10,000 independent repetitions). To reproduce the actual measuring process, we drew 10-plets of rebound values as well as values of temperatures for each measuring point in each of the three blocks at each measuring time (300 rebound values and 30 temperature values at each measuring time). We imposed normal distributions for all variables, derived from the empirical values (Table 3).

We then proceeded to calculate the mean rebound numbers and temperatures, and thus the strength and CRIs for each block, and analysed the distribution of $\mathrm{R}^{2}$ values resulting from the linear regressions for each repetition. We obtained median $\mathrm{R}^{2}$ values of 0.67, 0.40, 0.93, and 0.92 between $\sigma_{\mathrm{c}}$ and $\mathrm{CRI}_{1 \mathrm{~h}}, \mathrm{CRI}_{2 \mathrm{~h}}, \mathrm{CRI}_{5 \mathrm{~h}}$, and Total CRI, respectively. We calculated selected percentiles of the distributions of $R^{2}$ and slope values $(\mathrm{m})$ of the regression (Table 3$)$, based on which we can infer a positive correlation $(\mathrm{m}>0)$ between $\sigma_{\mathrm{C}}$ and $\mathrm{CRI}_{5 \mathrm{~h}}(p$-value $<0.01)$ and between $\sigma_{\mathrm{c}}$ and Total CRI $(p$-value $<0.001)$. For the $\sigma_{\mathrm{c}}-\mathrm{CRI}_{5 \mathrm{~h}}$ and $\sigma_{\mathrm{c}}-$ Total CRI regressions we can also infer $(p$-value $<0.05)$ that $\mathrm{R}^{2}>0.44$ and $\mathrm{R}^{2}>0.50$, respectively. In other words, we can affirm that the thermal behaviour, through 5-h (or total) cooling rate index, can account for at least $44 \%$ (or 50\%) of the variance observed in the compressive strength. On the other hand, we cannot infer with sufficient confidence the existence of a positive correlation between $\sigma_{\mathrm{C}}$ and $\mathrm{CRI}_{1 \mathrm{~h}}(p$-value $>0.05)$, or between $\sigma_{\mathrm{c}}$ and $\mathrm{CRI}_{2 \mathrm{~h}}(p$-value $>0.05)$. Indeed, at $p$-value $=0.05$, the data appear uncorrelated $\left(\mathrm{R}^{2}<0.02\right)$ in both cases. 
Table 3. Input and output of a Monte-Carlo simulation (10,000 independent repetitions) to assess correlations between rebound number-derived compressive strength and cooling rate indices with different time spans. $\mathrm{R}^{2}$ and $\mathrm{m}$ are the coefficient of determination and the slope of the linear regression between $\sigma_{c}$ and CRI (i.e., $\sigma_{c}=m \cdot C R I+q$ ); perc. $=$ percentile.

\begin{tabular}{|c|c|c|c|c|c|c|c|c|c|c|c|c|c|c|}
\hline \multicolumn{15}{|c|}{ Input } \\
\hline \multirow{2}{*}{ Block } & \multicolumn{2}{|c|}{ Rebound } & \multicolumn{2}{|c|}{$\mathrm{T}$ at $\mathrm{t}=12: 00$} & & \multicolumn{2}{|c|}{$T$ at $t=13: 00$} & \multicolumn{2}{|c|}{$T$ at $t=14: 00$} & \multicolumn{3}{|c|}{$T$ at $t=17: 00$} & \multicolumn{2}{|c|}{$\mathrm{T}$ at $\mathrm{t}=7: 00$} \\
\hline & Mean & SD & Mean & SD & & Mean & SD & Mean & SD & Mean & SD & & Mean & SD \\
\hline A & 53 & 9 & 42.09 & 0.90 & & 41.19 & 0.75 & 39.15 & 0.55 & 32.13 & 0.45 & & 23.74 & 0.43 \\
\hline B & 49 & 11 & 41.02 & 0.74 & & 40.50 & 0.70 & 39.03 & 0.45 & 32.20 & 0.54 & & 23.78 & 0.43 \\
\hline C & 60 & 5 & 45.51 & 1.53 & & 44.52 & 1.89 & 43.02 & 2.20 & 33.64 & 0.65 & & 21.92 & 0.99 \\
\hline \multicolumn{15}{|c|}{ Output } \\
\hline \multirow[b]{2}{*}{ Statistic } & \multicolumn{7}{|c|}{$R^{2}$ of $\sigma_{c}$ vs.: } & \multicolumn{7}{|c|}{ m of $\sigma_{c}$ vs.: } \\
\hline & \multicolumn{2}{|c|}{$\mathrm{CRI}_{1 \mathrm{~h}}$} & $\mathrm{CRI}_{2 \mathrm{~h}}$ & \multicolumn{3}{|c|}{$\mathrm{CRI}_{5 \mathrm{~h}}$} & Total CRI & \multicolumn{2}{|l|}{$\mathrm{CRI}_{1 \mathrm{~h}}$} & $\mathrm{CRI}_{2 \mathrm{~h}}$ & & $\mathrm{CRI}_{5 \mathrm{~h}}$ & \multicolumn{2}{|c|}{$\begin{array}{c}\text { Total } \\
\text { CRI }\end{array}$} \\
\hline \multirow{5}{*}{$\begin{array}{c}0.1 \text { perc. } \\
1 \text { st perc. } \\
5 \text { th perc. } \\
\text { mean } \\
\text { median }\end{array}$} & \multicolumn{2}{|c|}{0.00} & 0.00 & \multicolumn{3}{|c|}{0.01} & 0.02 & \multicolumn{2}{|l|}{$<0$} & $<0$ & & $<0$ & \multicolumn{2}{|c|}{113} \\
\hline & \multicolumn{2}{|c|}{0.00} & 0.00 & \multicolumn{3}{|c|}{0.13} & 0.24 & \multicolumn{2}{|l|}{$<0$} & $<0$ & & 1908 & \multicolumn{2}{|c|}{4259} \\
\hline & \multicolumn{2}{|c|}{0.01} & 0.00 & \multicolumn{3}{|c|}{0.44} & 0.50 & \multicolumn{2}{|l|}{$<0$} & $<0$ & & 3850 & \multicolumn{2}{|c|}{7576} \\
\hline & \multicolumn{2}{|c|}{0.59} & 0.45 & \multicolumn{3}{|c|}{0.86} & 0.86 & \multicolumn{2}{|l|}{1972} & 2557 & & 8969 & \multicolumn{2}{|c|}{15227} \\
\hline & \multicolumn{2}{|c|}{0.67} & 0.40 & \multicolumn{3}{|c|}{0.93} & 0.92 & 2663 & & 2768 & & 8628 & & 167 \\
\hline
\end{tabular}

The observations involving $\mathrm{CRI}_{1 \mathrm{~h}}$ and $\mathrm{CRI}_{2 \mathrm{~h}}$ are certainly affected by the comparatively small decrease of temperature (with respect to its spatial variability) evaluated in the first two hours of cooling. In other words, the excessive "signal-to-noise" ratio hinders conclusions in short time spans. Conversely, as already mentioned, there is little difference between the inferences for $\mathrm{CRI}_{5 \mathrm{~h}}$ and the Total CRI. The former can, in a time span of five hours (29\% of the total cooling time), account for about half (50-54\%) of the total cooling. Therefore, the use of $\mathrm{CRI}_{5 \mathrm{~h}}$ should be preferred owing that it can be calculated after a much shorter monitoring period.

\section{Conclusions}

We have identified a strong correlation between the cooling rate index of rock blocks in a coastal cliff prone to rockfalls-evaluated through infrared thermography-and their compressive strength-evaluated by the rebound hammer test. Such correlation could be useful for characterising cliff portions that are unreachable for direct geomechanical surveying. The identification of the first five hours of cooling (after the temperature peak at midday) as the most informative time interval for regression analysis suggests that thermal sensing can be more effectively performed in the afternoon hours rather than over a complete 24-h cycle. The quantitative analysis of the thermograms can also highlight different heating-cooling patterns related to different lithologies, structures, and fracture sizes/apertures. Therefore, it can constitute a valid aid in rock and fracture network classifications. Infrared thermography can be flexibly applied at various spatial scales: few repeated flights of an UAV equipped with a thermal camera, performed during a cooling phase, can be sufficient to characterise the strength of unreachable blocks after establishing an empirical correlation based on field strength measurements. In principle, thermal information obtained by spaceborne sensors could also be related to that obtained by UAVs and ground-based sensors for studies with larger spatial coverage. However, in such cases, the limitations related to the achievable resolution, the opacity of the atmosphere to certain wavelengths, and the fixed passing times of the satellites should be addressed. With respect to the investigation of limited portions of a cliff, such as in the case study presented herein, the proposed methodology appears solid. However, further validation is needed in different settings (climates, seasons, meteorological conditions, lithologies, geometries), so as to explore multi-variate correlations applicable over larger areas, and 
aid in the formulation, calibration, and validation of thermo-hydro-mechanical models of rock faces.

Supplementary Materials: The following are available online at https:/ / www.mdpi.com/article/10 $.3390 /$ rs13071265/s1. Table S1: Primary spectral regions used in remote sensing. Table S2: Degree of fracturing based on the volumetric joint count). Table S3: Specifications of the FLIR XT2 camera. Table S4: Data from the weather station, external and internal data of the station, and laser thermometer data. Table S5: Strength classification of rocks.

Author Contributions: Conceptualisation and methodology, M.L., G.S., J.B., M.T.M., A.F., S.D.P., I.E., G.D. and M.A.M.; formal analysis, M.L., G.S. and J.B.; investigation, M.L. and I.E.; data curation, and original draft preparation, M.L.; review and editing, M.L., G.S., J.B., M.T.M., A.F., S.D.P., G.D., M.A.M. and F.C.; visualisation, M.L.; supervision, G.S. and M.T.M.; project administration, A.F. and G.S., funding acquisition, G.S., M.T.M., A.F. and S.D.P. All authors have read and agreed to the published version of the manuscript.

Funding: The experimental work was funded by Project MAREGOT under the Program: 20142020 INTERREG V-A Italy-France (Maritime). The first author appreciates the financial support given by the Charles University Grant Agency (GAUK) with project number 337121. Data analysis, manuscript preparation and publication were funded by the Grant Agency of the Czech Republic (GAČR Grant No. 20-28853Y) and the Fund for international mobility of researchers at Charles University (MSCA-IF IV; Project No. CZ.02.2.69/0.0/0.0/20_079/0017987).

Institutional Review Board Statement: Not applicable.

Informed Consent Statement: Not applicable.

Data Availability Statement: Elaborated data are presented in the manuscript. Raw experimental data can be provided by the authors upon reasonable request.

Conflicts of Interest: The authors declare no conflict of interest. The funders had no role in the design of the study; in the collection, analyses, or interpretation of data; in the writing of the manuscript, or in the decision to publish the results.

\section{References}

1. Priest, S.D. Discontinuity Analysis for Rock Engineering; Springer: Dordrecht, The Netherlands, 1995; ISBN 978-94-011-1498-1.

2. Bieniawski, Z.T. Engineering Rock Mass Classifications: A Complete Manual for Engineers and Geologists in Mining, Civil and Petroleum Engineering; Wiley: New York, NY, USA, 1989; ISBN 978-0-471-60172-2.

3. Elmo, D.; Stead, D. An Integrated Numerical Modelling-Discrete Fracture Network Approach Applied to the Characterisation of Rock Mass Strength of Naturally Fractured Pillars. Rock Mech. Rock Eng. 2010, 43, 3-19. [CrossRef]

4. Bieniawski, Z.T. Engineering Classification of Jointed Rock Masses. Trans. Afr. Inst. Civ. Eng. 1973, 12, 335-344.

5. Bieniawski, Z.T. Classification of Rock Masses for Engineering: The RMR System and Future Trends. In Rock Testing and Site Characterization; Elsevier: Amsterdam, The Netherlands, 1993; pp. 553-573. ISBN 978-0-08-042066-0.

6. Schweigl, J.; Ferretti, C.; Nössing, L. Geotechnical Characterization and Rockfall Simulation of a Slope: A Practical Case Study from South Tyrol (Italy). Eng. Geol. 2003, 67, 281-296. [CrossRef]

7. Volkwein, A.; Schellenberg, K.; Labiouse, V.; Agliardi, F.; Berger, F.; Bourrier, F.; Dorren, L.K.A.; Gerber, W.; Jaboyedoff, M. Rockfall Characterisation and Structural Protection-A Review. Nat. Hazards Earth Syst. Sci. 2011, 11, 2617-2651. [CrossRef]

8. Aggistalis, G.; Alivizatos, A.; Stamoulis, D.; Stournaras, G. Correlating Uniaxial Compressive Strength with Schmidt Hardness, Point Load Index, Young's Modulus, and Mineralogy of Gabbros and Basalts (Northern Greece). Bull. Int. Assoc. Eng. Geol. 1996, 54, 3-11. [CrossRef]

9. Aydin, A. ISRM Suggested Method for Determination of the Schmidt Hammer Rebound Hardness: Revised Version. Int. J. Rock Mech. Min. Sci. 2009, 46, 627-634. [CrossRef]

10. British Standards Institution. Natural Stone Test Methods. Determination of Compressive Strength; British Standards Institution: London, UK, 1999.

11. Katz, O.; Reches, Z.; Roegiers, J.-C. Evaluation of Mechanical Rock Properties Using a Schmidt Hammer. Int. J. Rock Mech. Min. Sci. 2000, 37, 723-728. [CrossRef]

12. Karakus, M.; Tutmez, B. Fuzzy and Multiple Regression Modelling for Evaluation of Intact Rock Strength Based on Point Load, Schmidt Hammer and Sonic Velocity. Rock Mech. Rock Eng. 2006, 39, 45-57. [CrossRef]

13. Goudie, A.S. The Schmidt Hammer in Geomorphological Research. Prog. Phys. Geogr. Earth Environ. 2006, 30, 703-718. [CrossRef]

14. Çobanoğlu, İ; Çelik, S.B. Estimation of Uniaxial Compressive Strength from Point Load Strength, Schmidt Hardness and P-Wave Velocity. Bull. Eng. Geol. Environ. 2008, 67, 491-498. [CrossRef] 
15. Fan, X.; Xu, Q.; Scaringi, G. Brief Communication: Post-Seismic Landslides, the Tough Lesson of a Catastrophe. Nat. Hazards Earth Syst. Sci. 2018, 18, 397-403. [CrossRef]

16. Melis, M.T.; Da Pelo, S.; Erbì, I.; Loche, M.; Deiana, G.; Demurtas, V.; Meloni, M.A.; Dessì, F.; Funedda, A.; Scaioni, M.; et al. Thermal Remote Sensing from UAVs: A Review on Methods in Coastal Cliffs Prone to Landslides. Remote Sens. 2020, $12,1971$. [CrossRef]

17. Froude, M.J.; Petley, D.N. Global Fatal Landslide Occurrence from 2004 to 2016. Nat. Hazards Earth Syst. Sci. 2018, 18, $2161-2181$. [CrossRef]

18. Fell, R.; Corominas, J.; Bonnard, C.; Cascini, L.; Leroi, E.; Savage, W.Z. Guidelines for Landslide Susceptibility, Hazard and Risk Zoning for Land Use Planning. Eng. Geol. 2008, 102, 85-98. [CrossRef]

19. Deiana, G.; Melis, M.T.; Funedda, A.; da Pelo, S.; Meloni, M.; Naitza, L.; Orrù, P.; Salvini, R.; Sulis, A. Integrating remote sensing data for the assessments of coastal cliffs hazard: MAREGOT project. In Earth Observation Advancements in a Changing World; Associazione Italiana di Telerilevamento (AIT): Florence, Italy, 2019; Volume 1, pp. 176-181.

20. Mazzanti, P.; Brunetti, A.; Bretschneider, A. A New Approach Based on Terrestrial Remote-sensing Techniques for Rock Fall Hazard Assessment. In Modern Technologies for Landslide Monitoring and Prediction; Scaioni, M., Ed.; Springer Natural Hazards; Springer: Berlin/Heidelberg, Germany, 2015; pp. 69-87. ISBN 978-3-662-45931-7.

21. Sunamura, T. Rocky Coast Processes: With Special Reference to the Recession of Soft Rock Cliffs. Proc. Jpn. Acad. Ser. B 2015, 91, 481-500. [CrossRef]

22. De Vita, P.; Cevasco, A.; Cavallo, C. Detailed Rock Failure Susceptibility Mapping in Steep Rocky Coasts by Means of Non-Contact Geostructural Surveys: The Case Study of the Tigullio Gulf (Eastern Liguria, Northern Italy). Nat. Hazards Earth Syst. Sci. 2012, 12, 867-880. [CrossRef]

23. Martino, S.; Mazzanti, P. Integrating Geomechanical Surveys and Remote Sensing for Sea Cliff Slope Stability Analysis: The Mt. Pucci Case Study (Italy). Nat. Hazards Earth Syst. Sci. 2014, 14, 831-848. [CrossRef]

24. Scaringi, G.; Fan, X.; Xu, Q.; Liu, C.; Ouyang, C.; Domènech, G.; Yang, F.; Dai, L. Some Considerations on the Use of Numerical Methods to Simulate Past Landslides and Possible New Failures: The Case of the Recent Xinmo Landslide (Sichuan, China). Landslides 2018, 15, 1359-1375. [CrossRef]

25. De Pippo, T.; Donadio, C.; Pennetta, M.; Petrosino, C.; Terlizzi, F.; Valente, A. Coastal Hazard Assessment and Mapping in Northern Campania, Italy. Geomorphology 2008, 97, 451-466. [CrossRef]

26. Pena, S.B.; Abreu, M.M.; Magalhães, M.R. Rethinking Coastal Cliff Protection Zones for Landscape Planning. What Limits are Enough? Appl. Geogr. 2021, 127, 102387. [CrossRef]

27. White, A.F.; Blum, A.E. Effects of Climate on Chemical_Weathering in Watersheds. Geochim. Cosmochim. Acta 1995, 59, 1729-1747. [CrossRef]

28. Ferrier, K.L.; Huppert, K.L.; Perron, J.T. Climatic Control of Bedrock River Incision. Nature 2013, 496, 206-209. [CrossRef]

29. Oliva, P.; Viers, J.; Dupré, B. Chemical Weathering in Granitic Environments. Chem. Geol. 2003, 202, 225-256. [CrossRef]

30. Colomina, I.; Molina, P. Unmanned Aerial Systems for Photogrammetry and Remote Sensing: A Review. ISPRS J. Photogramm. Remote Sens. 2014, 92, 79-97. [CrossRef]

31. Westoby, M.J.; Brasington, J.; Glasser, N.F.; Hambrey, M.J.; Reynolds, J.M. 'Structure-from-Motion' Photogrammetry: A Low-Cost, Effective Tool for Geoscience Applications. Geomorphology 2012, 179, 300-314. [CrossRef]

32. Hamshaw, S.D.; Engel, T.; Rizzo, D.M.; O’Neil-Dunne, J.; Dewoolkar, M.M. Application of Unmanned Aircraft System (UAS) for Monitoring Bank Erosion along River Corridors. Geomat. Nat. Hazards Risk 2019, 10, 1285-1305. [CrossRef]

33. Deffontaines, B.; Chang, K.-J.; Champenois, J.; Fruneau, B.; Pathier, E.; Hu, J.-C.; Lu, S.-T.; Liu, Y.-C. Active Interseismic Shallow Deformation of the Pingting Terraces (Longitudinal Valley-Eastern Taiwan) from UAV High-Resolution Topographic Data Combined with InSAR Time Series. Geomat. Nat. Hazards Risk 2017, 8, 120-136. [CrossRef]

34. Turner, D.; Lucieer, A.; de Jong, S. Time Series Analysis of Landslide Dynamics Using an Unmanned Aerial Vehicle (UAV). Remote Sens. 2015, 7, 1736-1757. [CrossRef]

35. Shannon, H.R.; Sigda, J.M.; van Dam, R.L.; Hendrickx, J.M.H.; McLemore, V.T. Thermal Camera Imaging of Rock Piles at the Questa Molybdenum Mine, Questa, New Mexico. J. Am. Soc. Min. Reclam. 2005, 2005, 1015-1028. [CrossRef]

36. Prendes-Gero, M.B.; Suárez-Domínguez, F.J.; González-Nicieza, C.; Álvarez-Fernández, M.I. Infrared Thermography Methodology Applied to Detect Localized Rockfalls in Self-Supporting Underground Mines. In Proceedings of the ISRM-EUROCK-2013-129, Wroclaw, Poland, 23-26 September 2013; Taylor \& Francis Group: London, UK, 2013; p. 5.

37. Teza, G.; Marcato, G.; Castelli, E.; Galgaro, A. IRTROCK: A MATLAB Toolbox for Contactless Recognition of Surface and Shallow Weakness of a Rock Cliff by Infrared Thermography. Comput. Geosci. 2012, 45, 109-118. [CrossRef]

38. Kuenzer, C.; Dech, S. (Eds.) Thermal Infrared Remote Sensing: Sensors, Methods, Applications; Remote Sensing and Digital Image Processing; Springer: Dordrecht, The Netherlands, 2013; ISBN 978-94-007-6639-6.

39. Mineo, S.; Pappalardo, G.; Rapisarda, F.; Cubito, A.; Di Maria, G. Integrated Geostructural, Seismic and Infrared Thermography Surveys for the Study of an Unstable Rock Slope in the Peloritani Chain (NE Sicily). Eng. Geol. 2015, 195, 225-235. [CrossRef]

40. Hillel, D. Introduction to Environmental Soil Physics; Elsevier Academic Press: Amsterdam, The Netherlands; Boston, MA, USA, 2004; ISBN 978-0-08-049577-4.

41. Pappalardo, G.; Mineo, S.; Zampelli, S.P.; Cubito, A.; Calcaterra, D. InfraRed Thermography Proposed for the Estimation of the Cooling Rate Index in the Remote Survey of Rock Masses. Int. J. Rock Mech. Min. Sci. 2016, 83, 182-196. [CrossRef] 
42. Hudson, R.D. Infrared System Engineering; Wiley-Interscience: New York, NY, USA; Sydney, NSW, Australia, 1969; ISBN 978-0-47141850-4.

43. Blackett, M. An Overview of Infrared Remote Sensing of Volcanic Activity. J. Imaging 2017, 3, 13. [CrossRef]

44. Oppenheimer, C.; Yirgu, G. Thermal Imaging of an Active Lava Lake: Erta 'Ale Volcano, Ethiopia. Int. J. Remote Sens. 2002, 23, 4777-4782. [CrossRef]

45. Lagios, E.; Vassilopoulou, S.; Sakkas, V.; Dietrich, V.; Damiata, B.N.; Ganas, A. Testing Satellite and Ground Thermal Imaging of Low-Temperature Fumarolic Fields: The Dormant Nisyros Volcano (Greece). ISPRS J. Photogramm. Remote Sens. 2007, 62, 447-460. [CrossRef]

46. Spampinato, L.; Calvari, S.; Oppenheimer, C.; Boschi, E. Volcano Surveillance Using Infrared Cameras. Earth Sci. Rev. 2011, 106, 63-91. [CrossRef]

47. Baroň, I.; Bečkovský, D.; Míča, L. Application of Infrared Thermography for Mapping Open Fractures in Deep-Seated Rockslides and Unstable Cliffs. Landslides 2014, 11, 15-27. [CrossRef]

48. Harvey, M.C.; Rowland, J.V.; Luketina, K.M. Drone with Thermal Infrared Camera Provides High Resolution Georeferenced Imagery of the Waikite Geothermal Area, New Zealand. J. Volcanol. Geotherm. Res. 2016, 325, 61-69. [CrossRef]

49. Pech, K.; Stelling, N.; Karrasch, P.; Maas, H.-G. Generation of Multitemporal Thermal Orthophotos from UAV Data; ISPRSInternational Archives of the Photogrammetry, Remote Sensing and Spatial Information Sciences; Copernicus GmbH: Göttingen, Germany, 2013; Volume XL-1-W2, pp. 305-310.

50. Gigli, G.; Frodella, W.; Garfagnoli, F.; Morelli, S.; Mugnai, F.; Menna, F.; Casagli, N. 3-D Geomechanical Rock Mass Characterization for the Evaluation of Rockslide Susceptibility Scenarios. Landslides 2014, 11, 131-140. [CrossRef]

51. Frodella, W.; Gigli, G.; Morelli, S.; Lombardi, L.; Casagli, N. Landslide Mapping and Characterization through Infrared Thermography (IRT): Suggestions for a Methodological Approach from Some Case Studies. Remote Sens. 2017, 9, 1281. [CrossRef]

52. Rossi, G.; Tanteri, L.; Tofani, V.; Vannocci, P.; Moretti, S.; Casagli, N. Multitemporal UAV Surveys for Landslide Mapping and Characterization. Landslides 2018, 15, 1045-1052. [CrossRef]

53. Frodella, W.; Elashvili, M.; Spizzichino, D.; Gigli, G.; Adikashvili, L.; Vacheishvili, N.; Kirkitadze, G.; Nadaraia, A.; Margottini, C.; Casagli, N. Combining InfraRed Thermography and UAV Digital Photogrammetry for the Protection and Conservation of Rupestrian Cultural Heritage Sites in Georgia: A Methodological Application. Remote Sens. 2020, 12. [CrossRef]

54. Pappalardo, G.; Mineo, S.; Imposa, S.; Grassi, S.; Leotta, A.; La Rosa, F.; Salerno, D. A Quick Combined Approach for the Characterization of a Cliff during a Post-Rockfall Emergency. Landslides 2020, 17, 1063-1081. [CrossRef]

55. Mineo, S.; Calcaterra, D.; Perriello Zampelli, S.; Pappalardo, G. Application of Infrared Thermography for the Survey of Intensely Jointed Rock Slopes. Rend. Online Soc. Geol. Ital. 2015, 35, 212-215. [CrossRef]

56. Pappalardo, G.; Mineo, S.; Marchese, G. Effects of Cubical Specimen Sizing on the Uniaxial Compressive Strength of Etna Volcanic Rocks (Italy). Ital. J. Eng. Geol. Environ. 2013, 2, 45-54.

57. Mineo, S.; Pappalardo, G. The Use of Infrared Thermography for Porosity Assessment of Intact Rock. Rock Mech. Rock Eng. 2016, 49, 3027-3039. [CrossRef]

58. Wu, J.-H.; Lin, H.-M.; Lee, D.-H.; Fang, S.-C. Integrity Assessment of Rock Mass behind the Shotcreted Slope Using Thermography. Eng. Geol. 2005, 80, 164-173. [CrossRef]

59. Pappalardo, G.; Mineo, S. Investigation on the Mechanical Attitude of Basaltic Rocks from Mount Etna through InfraRed Thermography and Laboratory Tests. Constr. Build. Mater. 2017, 134, 228-235. [CrossRef]

60. Fiorucci, M.; Marmoni, G.M.; Martino, S.; Mazzanti, P. Thermal Response of Jointed Rock Masses Inferred from Infrared Thermographic Surveying (Acuto Test-Site, Italy). Sensors 2018, 18, 2221. [CrossRef] [PubMed]

61. Grechi, G.; Martino, S. Preliminary Results from Multitemporal Infrared Thermography Surveys at the Wied-Il-Mielah Rock Arch (Island of Gozo). Ital. J. Eng. Geol. Env. 2019, 41-46. [CrossRef]

62. Barca, S.; Melis, E.; Annino, E.; Cincotti, F.; Ulzega, A.; Orru, P.; Pintus, C. Note Illustrative Della Carta Geologica d'Italia; Foglio 557 Cagliari, Scala 1:50.000; Servizio Geologico d'Italia: Rome, Italy, 2005.

63. Conte, A.M.; Cuccuru, S.; D'Antonio, M.; Naitza, S.; Oggiano, G.; Secchi, F.; Casini, L.; Cifelli, F. The Post-Collisional Late Variscan Ferroan Granites of Southern Sardinia (Italy): Inferences for Inhomogeneity of Lower Crust. Lithos 2017, 294-295, 263-282. [CrossRef]

64. Funedda, A.; Naitza, S.; Buttau, C.; Cocco, F.; Dini, A. Structural Controls of Ore Mineralization in a Polydeformed Basement: Field Examples from the Variscan Baccu Locci Shear Zone (SE Sardinia, Italy). Minerals 2018, 8, 456. [CrossRef]

65. Carmignani, L.; Oggiano, G.; Funedda, A.; Conti, P.; Pasci, S. The Geological Map of Sardinia (Italy) at 1:250,000 Scale. J. Maps 2016, 12, 826-835. [CrossRef]

66. Cocco, F.; Funedda, A.; Patacca, E.; Scandone, P. Plio-Pleistocene Extensional Tectonics in the Campidano Graben (SW Sardinia, Italy): Preliminary Note. Rend. Online Soc. Geol. Ital. 2013, 29, 31-34.

67. Palmström, A. The Volumetric Joint Count-A Useful and Simple Measure of the Degree of Rock Mass Jointing. Int. Assoc. Eng. Geol. Int. Congr. 1982, 4, 221-228.

68. Aydin, A.; Basu, A. The Schmidt Hammer in Rock Material Characterization. Eng. Geol. 2005, 81, 1-14. [CrossRef]

69. Öhman, C. Emittansmätningar Med AGEMA E-Box; TFeknisk Rapport; AGEMA: Kalmar, Sweden, 1999.

70. Deere, D.U.; Miller, R.P. Engineering Classification and Index Properties for Intact Rock; Defense Technical Information Center: Fort Belvoir, VA, USA, 1966. 